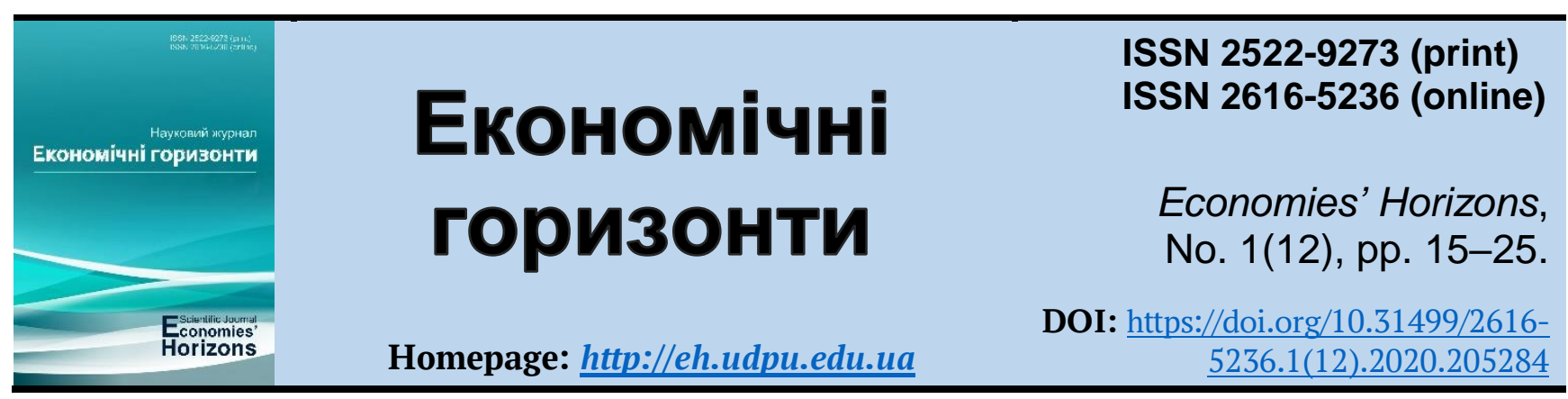

UDC 336.025:332.142.2

\title{
Methodical provision of financial security assessment of the state
}

\author{
Iryna V. Zaichko ${ }^{1}$
}

Received: 24 January 2020

Accepted: 26 February 2020
Zaichko, I. V. (2020), "Methodical provision of financial security assessment of the state", Economies' Horizons, no. 1(12), pp. 15-25. doi: https://doi.org/10.31499/26165236.1(12).2020.205284.

Abstract. Purpose of the research. The main purpose of the article is to improve methodological support for the assessment of the financial security of the state, taking into account the impact of budgetary policy. Methodology. During the study the following methods were applied: comparative analysis, integral estimation, normalization of indicators, component analysis, method of principal components, etc. Results. In the course of comparing the existing methodological support for the financial security assessment, it is justified, notwithstanding the existing shortcomings, the expediency of applying in the analytical work the Methodological recommendations for the calculation of the economic security level of Ukraine of the Ministry of Economic Development and Trade of Ukraine (2013) and the necessary calculations of the level of financial security of Ukraine for 2009-2018. Additional financial security indicators are proposed, taking into account the priority of its budget component, in particular, the share of revenues from the National Bank of Ukraine (NBU) in the state budget revenues (for banking security), the ratio of the pension contributions of non-state pension funds to the own income of the Pension Fund of Ukraine (PFU) market), government revenue as a percentage of consolidated budget expenditures and the share of public servicing and debt repayment expenditures in consolidated budget expenditures (for debt security), expenditures and for servicing and repayment of public debt as \% of gross domestic product (GDP) (for fiscal security); consolidated budget revenues in USD US (for currency security), consumer loans to households, \% of household income, and lending to consolidated budget expenditures (for monetary security). On the basis of regression analysis, where sub-indices of functional constituents are taken by factor signs, and the integral indicator of financial security is obtained as a result sign, the reliability of the calculations is confirmed. Practical meaning. The calculated sub-indices of the functional components of the financial security of Ukraine and the integrated indicator for 2009-2018 can be used in the development of plans, forecasts, strategies for socio-economic development of Ukraine. Prospects for further research of the author are to study the impact of budgetary policy on the state of financial security of Ukraine.

Keyword: financial security, sub-index, integrated indicator, methodology, indicator.

JEL Classification: C38, G28, F52, H12.

Number of references: 25; number of tables: 2; number of figures: 2; number of formulas: $\mathbf{0 .}$

\footnotetext{
${ }^{1}$ Kyiv National University of Culture and Arts; Senior Lecturer at the Research Institute; ORCID ID: https://orcid.org/0000-0002-6080-2959; e-mail: zkiv26@gmail.com; Scientific Adviser - Taisiya H. Bondaruk, Doct. Ec. Sc., Professor.
} 


\title{
Методичне забезпечення оцінки фінансової безпеки держави
}

\author{
Ірина Володимирівна Заїчко 1
}

Стаття надійшла: 24.01.2020

Стаття прийнята: 26.02.2020
Zaichko I. V. Methodical provision of financial security assessment of the state. Економічні горизонти. 2020. № 1(12). C. 15-25. DOI: 10.31499/26165236.1(12).2020.205284.

Анотація. Мета дослідження. Головна мета статті полягає в удосконаленні методичного забезпечення оцінки фінансової безпеки держави з урахуванням впливу бюджетної політики. $M e$ тодологія. У ході дослідження застосовано такі методи: порівняльного аналізу, інтегрального оцінювання, нормування показників, компонентний аналіз, метод головних компонент тощо. $\mathrm{Pe}$ зультати. У ході порівняння існуючого методичного забезпечення оцінки фінансової безпеки обгрунтовано, не зважаючи на існуючі недоліки, доцільність застосування у аналітичній роботі Методичних рекомендацій щодо розрахунку рівня економічної безпеки України Міністерства економічного розвитку і торгівлі України (2013) та проведено необхідні розрахунки рівня фінансової безпеки України за 2009-2018 рр. Запропоновано додаткові індикатори фінансової безпеки з урахуванням пріоритетності її бюджетної складової, зокрема частка надходжень від НБУ в доходах державного бюджету (для банківської безпеки), відношення обсягу пенсійних внесків недержавних пенсійних фондів до власних доходів Пенсійного фонду України (ПФУ) (для безпеки небанківського фінансового ринку), надходження від ОВДП у \% до видатків зведеного бюджету та частка витрат на обслуговування та погашення державного боргу у видатках зведеного бюджету (для боргової безпеки), витрати на обслуговування та погашення державного боргу у \% до валового внутрішнього продукту (ВВП) (для бюджетної безпеки); доходи зведеного бюджету в дол. США (для валютної безпеки), обсяг споживчих кредитів, наданих домогосподарствам, у \% до доходів населення та частка кредитування у видатках зведеного бюджету (для грошово-кредитної безпеки). На основі регресійного аналізу, де факторними ознаками взято субіндекси функціональних складових, а результуючою ознакою - інтегральний показник фінансової безпеки, підтверджено достовірність проведених розрахунків. Практичне значення. Розраховані значення субіндексів функціональних складових фінансової безпеки України та інтегрального показника за 2009-2018 році можуть бути використані при розробці планів, прогнозів, стратегії соціальноекономічного розвитку України. Перспективи подальщих досліджень автора полягають у дослідженні впливу бюджетної політики на стан фінансової безпеки України.

Ключові слова: фінансова безпека, субіндекс, інтегральний показник, методика, індикатор.

Кількість джерел: 25; кількість таблищь: 2; кількість рисунків: 2; кількість формул: 0.

\section{Introduction.}

Financial security is a reflection of the state of the financial system and the result of protective measures of financial and in particular budgetary policy of the state to counter existing internal and external threats, which exist both objectively and unconditionally on a permanent basis and may occur periodically (temporarily, seasonally, etc.) from the nature of the impact and the direction of the risks.
Financial security is a strategic priority of public policy in the field of finance, in connection with which the study of ways of its methodological support is an urgent scientific problem, the solution of which depends on both the efficiency of the national economy and economic development.

\section{Literature review.}

The theoretical and methodological aspects of the formation and formation of

${ }^{1}$ Київський національний університет культури і мистецтв, старший викладач науково-дослідного інституту, ідентифікатор ORCID: https://orcid.org/0000-0002-6080-2959; e-mail: zkiv26@gmail.com; науковий керівник - Таїсія Григорівна Бондарук, д. е. н., професор. 
financial security of the state are devoted to the work of many scientists. The proposed study is based on the work of authors such as: N. Semjonova (2016), G. Thompson (2017), L. Guryanova et al. (2017), O. Ivanova, T. Romanova, E. Kostoglodova, and D. Romanov (2017), P. Siemiątkowski (2017), M. Goede (2017), R. Han (2018), J. Haber et al. (2018), A. Lyons, J. Grable, and S.-H. Joo (2018), N. Biloshkurska, M. Biloshkurskyi and V. Omelyanenko (2018), V. Tkachenko et al. (2019), T. Munyon, A. Carnes, L. Lyons and I. Zettler (2019), T. Bondaruk, O. Bondaruk and A. Kulish (2019), H. Telnova and B. Malovanyy (2019), T. Ponomarenko et al. (2019) etc.

However, the solution of the problem of methodological support for the assessment of financial security of the state is unsystematic, multi-vector and insufficiently developed in the scientific literature, so it needs further research.

\section{Methods.}

The following methods were used in the study: comparative analysis, integrated evaluation, standardization of indicators, component analysis, principal components method, etc.

\section{Research objectives.}

The main purpose of the study is to improve the methodological support for assessing the financial security of the state, taking into account the impact of fiscal policy.

\section{Results and discussions.}

Based on the analysis of scientific works of leading domestic scientists, which was conducted to study the existing methodological support for assessing the financial security of the state, we distinguish 3 basic methods:

- Methodical recommendations for assessing the level of economic security of Ukraine S. Pyrozhkov (ed.) (2003);

- Methodology for calculating the level of economic security of Ukraine of the Ministry of Economy of Ukraine (2007), has expired;

- Methodical recommendations for calculating the level of economic security of Ukraine of the Ministry of Economic
Development and Trade of Ukraine (2013), approved instead of the previous one.

In each method, financial security is interpreted as a component of economic security of the state.

We will conduct a comparative analysis of methodological approaches to the definition, classification and formalization of financial security, based on the main provisions of the 3 basic methods. The results of the comparative analysis are summarized in Table 1.

From the data presented in Table 1, it is possible to trace both the evolution of the concept of "financial security" and the components and indicators that formalize it and provide a quantitative dimension during 20032013. Thus, in each of the definitions financial security is interpreted as a state financial system of the country (detailing the components of the financial system in the first and second definition), characterized by the ability to ensure efficiency and stability of the state with an emphasis on globalization in the first definition, with clarification on resilience to internal and external threats and economic growth in the second definition. addition to the preservation of the integrity of the financial system, taking into account the resilience of the economy to financial shocks and imbalances.

Formalization of financial security in the first method (Pyrozhkov, 2003) was proposed on the basis of 6 indicators (inflation rate; domestic debt to GDP; external debt to GDP; state budget deficit to GDP; level of monetization of the economy to GDP; cost of bank loans; international reserves of the NBU), comparing their actual values with the corresponding thresholds. Guidelines (Pyrozhkov, 2003) was actually a report of the research "The economic security of Ukraine in the context of globalization and development crisis for the global economy", prepared by a team of scientists of the National Institute of International Security Problems of National Security and Defense Council of Ukraine headed by Academician NAS Ukraine S. Pyrozhkov and were of an introductory nature with the results of scientific research. 
Table 1. Comparative characteristics of the main methods of assessing financial security

\begin{tabular}{|c|c|c|c|}
\hline \multirow[b]{2}{*}{ Indicator } & \multicolumn{3}{|c|}{$\begin{array}{l}\text { Abbreviated name of methods for assessing the level of economic security of the state, year of } \\
\text { approval }\end{array}$} \\
\hline & $\begin{array}{l}\text { Methodical } \\
\text { recommendations, } \\
2003\end{array}$ & Methodology, 2007 & $\begin{array}{l}\text { Methodical } \\
\text { recommendations, } 2003\end{array}$ \\
\hline $\begin{array}{c}\text { Financial } \\
\text { security } \\
\text { is: }\end{array}$ & $\begin{array}{l}\text { the state of the financial, } \\
\text { monetary, budgetary, } \\
\text { monetary, banking and } \\
\text { tax systems, which can } \\
\text { ensure the effective } \\
\text { functioning of the state, } \\
\text { maintaining its eco- } \\
\text { nomic stability in the } \\
\text { global environment }\end{array}$ & $\begin{array}{l}\text { such a state of the budget, monetary, } \\
\text { banking, currency system and finan- } \\
\text { cial markets, which is characterized by } \\
\text { balance, resistance to internal and ex- } \\
\text { ternal negative threats, the ability to } \\
\text { ensure the effective functioning of the } \\
\text { national economic system and eco- } \\
\text { nomic growth }\end{array}$ & $\begin{array}{l}\text { the state of the country's finan- } \\
\text { cial system, which creates the } \\
\text { necessary financial conditions } \\
\text { for stable socio-economic de- } \\
\text { velopment of the country, en- } \\
\text { sures its resilience to financial } \\
\text { shocks and imbalances, creates } \\
\text { conditions for maintaining the } \\
\text { integrity and unity of the coun- } \\
\text { try's financial system }\end{array}$ \\
\hline $\begin{array}{l}\text { Compo- } \\
\text { nents of } \\
\text { financial } \\
\text { security }\end{array}$ & not isolated & $\begin{array}{c}\text { Total } 7 \text { components: } \\
\text { budget security (6 indicators); money } \\
\text { market security and inflation pro- } \\
\text { cesses (6 indicators); currency security } \\
\text { ( } 3 \text { indicators); debt security ( } 9 \text { indica- } \\
\text { tors); insurance market security (4 in- } \\
\text { dicators); stock market security (3 in- } \\
\text { dicators); banking security ( } 2 \text { indica- } \\
\text { tors) }\end{array}$ & $\begin{array}{c}\text { Total } 6 \text { components: } \\
\text { banking security ( } 7 \text { indicators); } \\
\text { security of the non-banking fi- } \\
\text { nancial market ( } 4 \text { indicators); } \\
\text { debt security ( } 5 \text { indicators); } \\
\text { budget security (4 indicators); } \\
\text { currency security (6 indica- } \\
\text { tors); monetary } \\
\text { security (6 indicators) }\end{array}$ \\
\hline $\begin{array}{l}\text { Indicators } \\
\text { of every- } \\
\text { thing }\end{array}$ & 7 indicators & 33 indicators & 32 indicators \\
\hline \multirow[t]{2}{*}{$\begin{array}{l}\text { Common } \\
\text { indicators }\end{array}$} & \multicolumn{3}{|c|}{$\begin{array}{l}\text { 1. The ratio of gross external debt to GDP; } \\
\text { 2. Ratio of state budget deficit / surplus to GDP } \\
\text { (only } 2 \text { indicators). }\end{array}$} \\
\hline & $x_{1}$ & \multicolumn{2}{|c|}{$\begin{array}{l}\text { 1. Share of foreign capital in the authorized capital of banks; } \\
\text { 2. Level of insurance penetration (insurance premiums to GDP); } \\
\text { 3. The level of capitalization of listed companies, interest on GDP; } \\
\text { 4. The ratio of public and state-guaranteed debt to GDP; } \\
\text { 5. The weighted average yield on domestic government bonds in the pri- } \\
\text { mary market; } \\
\text { 6. The level of redistribution of GDP through the consolidated budget; } \\
\text { 7. The ratio of total payments for external debt service to state budget } \\
\text { revenues; } \\
\text { 8. Index of change in the official exchange rate of the national currency } \\
\text { to the US dollar; } \\
\text { 9. The level of dollarization of the money supply; } \\
\text { 10. Gross international reserves of Ukraine, months of import; } \\
\text { 11. The level of the weighted average interest rate on loans granted by } \\
\text { deposit-taking corporations (excluding NBU) in national currency, rela- } \\
\text { tive to the consumer price index; } \\
\text { 12. The share of pre-term loans in the total amount of loans granted } \\
\text { (only } 12 \text { indicators). }\end{array}$} \\
\hline
\end{tabular}

Source: generalized and formed according to data (Pyrozhkov, 2003; Ministry of Economy of Ukraine, 2007; Ministry of Economic Development and Trade of Ukraine, 2013).

Based on the second methodology (Ministry of Economy of Ukraine, 2007) of a recommendatory nature, which was already approved for use at the level of the Ministry of Economy of Ukraine in 2007, annual calculations of the level of economic security of 
Ukraine, including financial security as its component, up to and including 2012. According to the Guidelines (Ministry of Economic Development and Trade of Ukraine, 2013), the formalization of financial security has already been carried out on 33 indicators by rationing them with the definition of optimal, threshold and threshold values for each indicator, as well as building an integrated indicator by principal components and using expert procedures. Also, the indicators were grouped into $7 \mathrm{com}$ ponents of financial security: budget (6 indicators); money market and inflation processes (6 indicators); currency (3 indicators); debt (9 indicators); insurance market (4 indicators); stock market (3 indicators); banking (2 indicators).

The third methodology (Ministry of Economic Development and Trade of Ukraine, 2013), also of a recommendatory nature, was approved for use at the level of the Ministry of Economy of Ukraine in 2013, as a result of which the second methodology (Ministry of Economy of Ukraine, 2007) expired. Analyzing the main provisions of the guidelines (Ministry of Economic Development and Trade of Ukraine, 2013), we can conclude that their implementation was caused by the new threats of the global financial crisis of 2008-2009 and the stagnation of 2012-2013, as replaced by about $60 \%$ of financial security indicators used in the previous methodology (Ministry of Economy of Ukraine, 2007), new, in particular indicators reflecting new threats, were: share of assets of the 5 largest banks in total assets of the banking system, insurance penetration rate, volatility level PFTS index, weighted average yield of domestic government bonds in the primary market, Emerging Markets Bond Index Ukraine, the balance of purchase and sale of foreign currency, the total amount of exported financial resources abroad, etc. (Ministry of Economic Development and Trade of Ukraine,
2013). In addition, two components were combined - security of the insurance and stock markets - in the security of the non-banking financial market, and the security of the money market and inflationary processes were transformed into monetary security.

The analyzed methodological recommendations are currently valid, the most modern, compared to the previous ones, take into account the most current risks and threats to financial security, are based on a new, improved method of standardization of indicators, which provides for the separation of 5 threshold (characteristic) values. The disadvantages of the methodological recommendations (Ministry of Economic Development and Trade of Ukraine, 2013) are the significant complexity of searching for official statistics and indicators based on them, as well as the lack of free access, including on the Internet, any analytical results regarding the calculation of the level of financial security. In this regard, for the implementation of the analytical part of the dissertation study of the place of budget policy in the system of financial security, there is a problem of analyzing the level of financial security of Ukraine. To solve this problem, the most acceptable are the "Guidelines for calculating the level of economic security of Ukraine" of the Ministry of Economic Development and Trade of Ukraine (2013), which provide for the formation of a set of 32 indicators, their rationing, and calculating levels of 6 sub-indices and integrated financial security. As open sources of information do not contain any analytical data of the Ministry of Economic Development and Trade of Ukraine on the calculation of financial security indicators of Ukraine, there is an urgent need to conduct an analytical study of the dynamics and structure of financial security of Ukraine during the study period 20092018 (Table 2). 
Table 2. Calculation of the level of financial security of the state on the basis of Methodical recommendations on calculation of the level of economic security of Ukraine (2013)

\begin{tabular}{|c|c|c|c|c|c|c|c|c|c|c|}
\hline Найменування показника & 2009 & 2010 & 2011 & 2012 & 2013 & 2014 & 2015 & 2016 & 2017 & 2018 \\
\hline 1 & 2 & 3 & 4 & 5 & 6 & 7 & 8 & 9 & 10 & 11 \\
\hline $\begin{array}{l}\text { 1. Share of overdue debt on loans in the total } \\
\text { amount of loans granted by banks to residents of } \\
\text { Ukraine, \% }\end{array}$ & 9.4 & 11.2 & 9.6 & 8.9 & 7.7 & 13.5 & 21.1 & 53.7 & 54.5 & 52.9 \\
\hline $\begin{array}{l}\text { 2. The ratio of bank loans and deposits in foreign } \\
\text { currency, } \%\end{array}$ & 109.8 & 81.0 & 65.7 & 52.3 & 46.0 & 70.0 & 76.4 & 62.2 & 49.6 & 49.2 \\
\hline $\begin{array}{l}\text { 3. The share of foreign capital in the authorized cap- } \\
\text { ital of banks, \% }\end{array}$ & 51 & 55 & 53 & 53 & 49 & 51 & 41 & 41 & 39 & 41 \\
\hline $\begin{array}{l}\text { 4. The ratio of pre-term (over } 1 \text { year) loans to de- } \\
\text { posits, times }\end{array}$ & 1.47 & 1.18 & 1.03 & 0.82 & 0.72 & 0.90 & 0.76 & 0.82 & 0.68 & 0.62 \\
\hline 5. Return on assets, \% & -4.4 & -1.5 & -0.7 & 0.5 & 0.3 & -4.2 & -5.5 & -12.5 & -1.8 & 1.6 \\
\hline $\begin{array}{l}\text { 6. The ratio of liquid assets to short-term liabilities, } \\
\%\end{array}$ & 35.9 & 91.2 & 94.7 & 90.3 & 89.1 & 86.1 & 92.9 & 92.1 & 98.4 & 93.5 \\
\hline $\begin{array}{l}\text { 7. Share of assets of the } 5 \text { largest banks in the total } \\
\text { assets of the banking system, } \%\end{array}$ & 34.5 & 36.8 & 36.6 & 38.7 & 40.0 & 43.5 & 53.0 & 54.9 & 87.3 & 90.0 \\
\hline $\begin{array}{l}\text { Banking security sub-index (weighting factor } \\
0.1723 \text { ) }\end{array}$ & 0.473 & 0.514 & 0.510 & 0.566 & 0.533 & 0.463 & 0.504 & 0.455 & 0.423 & 0.520 \\
\hline $\begin{array}{l}\text { 8. Insurance penetration rate (insurance premiums } \\
\text { to GDP), \% }\end{array}$ & 2.2 & 2.1 & 1.7 & 1.5 & 1.9 & 1.7 & 1.5 & 1.5 & 1.5 & 1.4 \\
\hline $\begin{array}{l}\text { 9. Level of capitalization of listed companies, \% of } \\
\text { GDP }\end{array}$ & 12.6 & 15.9 & 13.7 & 19.7 & 21.4 & 29.2 & 3.2 & 0.8 & 0.6 & 0.2 \\
\hline $\begin{array}{l}\text { 10. The level of volatility of the PFTS index, the } \\
\text { number of critical deviations }(-10 \%)\end{array}$ & 1 & 2 & 1 & 1 & 0 & 1 & 1 & 0 & 0 & 0 \\
\hline $\begin{array}{l}\text { 11. Share of insurance premium revenues of the } 3 \\
\text { largest insurance companies in the total revenue of } \\
\text { insurance premiums (excluding life insurance), } \%\end{array}$ & 11.2 & 13.6 & 13.7 & 9.9 & 13.5 & 15.6 & 14.7 & 18.9 & 21.3 & 15.0 \\
\hline $\begin{array}{l}\text { Non-banking financial market security sub-index } \\
\text { (weighting factor } 0.1068 \text { ) }\end{array}$ & 0.482 & 0.422 & $0.417 \mid$ & 0.485 & 0.489 & 0.460 & 0.341 & 0.320 & 0.304 & 0.342 \\
\hline $\begin{array}{l}\text { 12. The ratio of public and state-guaranteed debt to } \\
\text { GDP, \% }\end{array}$ & 33.46 & 38.57 & 35.07 & 35.33 & 38.36 & 69.35 & 79.06 & 80.90 & 71.77 & 60.91 \\
\hline 13. The ratio of gross external debt to GDP, $\%$ & 85.09 & 83.10 & 74.55 & 73.73 & 74.58 & 93.85 & 129.26 & 120.53 & 102.91 & 87.63 \\
\hline $\begin{array}{l}\text { 14. Weighted average yield on domestic govern- } \\
\text { ment bonds (IGLBs) in the primary market, \% }\end{array}$ & 12.21 & 10.39 & 9.17 & 12.94 & 13.13 & 13.98 & 13.07 & 9.16 & 10.47 & 17.79 \\
\hline 15. EMBI (Emerging Market Bond Index) Ukraine & 371.2 & 493.1 & 466.6 & 582.3 & 556.1 & 448.2 & 586.2 & 667.6 & 825.5 & 749.5 \\
\hline $\begin{array}{l}\text { 16. The ratio of official international reserves to } \\
\text { gross external debt, } \%\end{array}$ & 25.63 & 29.47 & 25.19 & 18.23 & 14.37 & 6.01 & 11.30 & 13.81 & 16.29 & 18.15 \\
\hline Debt security sub-index (weighting factor 0.1746 ) & 0.425 & 0.387 & 0.444 & 0.354 & 0.336 & 0.228 & 0.202 & 0.233 & 0.202 & 0.202 \\
\hline $\begin{array}{l}\text { 1 7. Ratio of state budget deficit / surplus to GDP, } \\
\%\end{array}$ & -3.75 & -5.73 & -1.75 & -3.66 & -4.25 & -4.92 & -2.27 & -2.94 & -1.60 & -1.66 \\
\hline $\begin{array}{l}\text { 18. Deficit / surplus of budgetary and extra-budget- } \\
\text { ary funds of the general government sector, \% of } \\
\text { GDP }\end{array}$ & -3.60 & $-0.67 \mid$ & -0.84 & -0.51 & 0.05 & -0.23 & -0.11 & 0.13 & 0.03 & -0.21 \\
\hline $\begin{array}{l}\text { 19. The level of redistribution of GDP through the } \\
\text { consolidated budget, } \%\end{array}$ & 28.82 & 28.07 & 29.54 & 30.53 & 29.08 & 28.74 & 32.79 & 32.81 & 34.08 & 33.26 \\
\hline $\begin{array}{l}\text { 20. The ratio of total payments for servicing and re- } \\
\text { payment of public debt to state budget revenues, \% }\end{array}$ & 4.72 & 7.30 & 7.82 & 7.44 & 10.14 & 14.29 & 16.24 & 15.80 & 14.05 & 12.53 \\
\hline $\begin{array}{l}\text { Budget security sub-index (weighting factor } \\
0.2023 \text { ) }\end{array}$ & 0.663 & 0.646 & 0.841 & 0.689 & 0.668 & 0.550 & 0.513 & 0.650 & 0.719 & 0.669 \\
\hline $\begin{array}{l}\text { 21. Index of change in the official exchange rate of } \\
\text { the national currency to the US dollar, the average } \\
\text { for the period }\end{array}$ & 147.9 & 101.9 & 100.4 & 100.3 & 100.0 & 148.7 & 183.8 & 117.0 & $\mid 104.1$ & 102.3 \\
\hline $\begin{array}{l}\text { 22. The difference between the forward and official } \\
\text { exchange rate of hryvnia, UAH }\end{array}$ & 0.003 & -0.001 & -0.049 & -0.017 & -0.302 & -0.411 & 0.001 & 0.141 & -0.003 & -0.072 \\
\hline $\begin{array}{l}\text { 23. Gross international reserves of Ukraine, months } \\
\text { of import }\end{array}$ & 4.8 & 5.7 & 3.9 & 3.3 & 2.7 & 1.7 & 2.2 & 3.7 & 3.6 & 3.4 \\
\hline $\begin{array}{l}\text { 24. Share of loans in foreign currency in the total } \\
\text { amount of loans, \% }\end{array}$ & 50.8 & 46.0 & 40.3 & 36.7 & 33.8 & 46.3 & 55.8 & 49.4 & 43.9 & 42.8 \\
\hline
\end{tabular}


Continuation of Table 2

\begin{tabular}{|l|c|c|c|c|c|c|c|c|c|c|}
\hline \multicolumn{1}{|c|}{$\mathbf{1}$} & $\mathbf{2}$ & $\mathbf{3}$ & $\mathbf{4}$ & $\mathbf{5}$ & $\mathbf{6}$ & $\mathbf{7}$ & $\mathbf{8}$ & $\mathbf{9}$ & $\mathbf{1 0}$ & $\mathbf{1 1}$ \\
\hline $\begin{array}{l}\text { 25. Balance of purchase and sale of foreign cur- } \\
\text { rency by the population, billion USD }\end{array}$ & 8.38 & 9.73 & 13.44 & 9.19 & 2.88 & 2.41 & 34.97 & 63.24 & 56.63 & 39.89 \\
\hline $\begin{array}{l}\text { 26. The level of dollarization of the money supply, } \\
\text { \% }\end{array}$ & 31.7 & 29.1 & 30.4 & 32.1 & 27.2 & 32.2 & 32.2 & 32.9 & 31.9 & 29.2 \\
\hline $\begin{array}{l}\text { Currency security sub-index (weighting factor } \\
\mathbf{0 . 1 6 8 6} \text { ) }\end{array}$ & $\mathbf{0 . 4 8 1}$ & $\mathbf{0 . 6 4 5}$ & $\mathbf{0 . 6 3 1}$ & $\mathbf{0 . 6 4 6}$ & $\mathbf{0 . 7 3 8}$ & $\mathbf{0 . 4 2 0}$ & $\mathbf{0 . 3 3 1}$ & $\mathbf{0 . 4 2 5}$ & $\mathbf{0 . 5 8 7}$ & $\mathbf{0 . 5 9 8}$ \\
\hline $\begin{array}{l}\text { 27. The share of cash outside banks in the total } \\
\text { money supply (M0 / M3), \% }\end{array}$ & 32.22 & 30.61 & 28.11 & 26.29 & 26.16 & 29.57 & 28.44 & 28.51 & 27.51 & 28.46 \\
\hline $\begin{array}{l}\text { 28. The difference between interest rates provided } \\
\text { by deposit-taking corporations in the reporting pe- } \\
\text { riod and interest rates on deposits attracted by de- } \\
\text { posit-taking institutions (excluding NBU), \% }\end{array}$ & 6.50 & 5.20 & 7.00 & 4.20 & 4.90 & 4.50 & 5.90 & 5.50 & 6.30 & 6.30 \\
\hline $\begin{array}{l}\text { 29. The level of the weighted average interest rate } \\
\text { on loans granted by deposit-taking corporations } \\
\text { (excluding NBU) in national currency, relative to } \\
\text { the consumer price index, \% }\end{array}$ & 5.02 & 6.25 & 7.96 & 17.80 & 16.93 & 5.52 & -26.87 & 4.64 & 1.96 & 8.23 \\
\hline $\begin{array}{l}\text { 30. Share of consumer loans to households in the } \\
\text { total structure of loans to residents, \% }\end{array}$ & 18.96 & 16.78 & 15.74 & 15.34 & 15.08 & 13.24 & 10.68 & 10.17 & 12.01 & 14.13 \\
\hline $\begin{array}{l}\text { 31. The share of long-term loans in the total amount } \\
\text { of loans granted (adjusted for exchange rate differ- } \\
\text { ences), \% }\end{array}$ & 31.19 & 29.26 & 25.37 & 21.64 & 19.10 & 21.29 & 21.81 & 25.88 & 26.44 & 22.76 \\
\hline $\begin{array}{l}\text { 32. The total amount of exported financial re- } \\
\text { sources outside the country, billion USD }\end{array}$ & 5.43 & 5.85 & 6.35 & 4.81 & 10.50 & 11.90 & 15.60 & 15.10 & 14.30 & 13.87 \\
\hline $\begin{array}{l}\text { Monetary security sub-index (weighting factor } \\
\mathbf{0 . 1 7 5 3 )}\end{array}$ & $\mathbf{0 . 5 4 4}$ & $\mathbf{0 . 5 7 5}$ & $\mathbf{0 . 5 0 4}$ & $\mathbf{0 . 6 5 2}$ & $\mathbf{0 . 5 9 0}$ & $\mathbf{0 . 5 9 1}$ & $\mathbf{0 . 4 1 0}$ & $\mathbf{0 . 5 8 0}$ & $\mathbf{0 . 5 3 9}$ & $\mathbf{0 . 4 6 6}$ \\
\hline An integrated indicator of financial security & $\mathbf{0 . 5 1 8}$ & $\mathbf{0 . 5 4 2}$ & $\mathbf{0 . 5 7 5}$ & $\mathbf{0 . 5 7 4}$ & $\mathbf{0 . 5 6 6}$ & $\mathbf{0 . 4 5 4}$ & $\mathbf{0 . 3 9 0}$ & $\mathbf{0 . 4 5 8}$ & $\mathbf{0 . 4 7 9}$ & $\mathbf{0 . 4 7 9}$ \\
\hline
\end{tabular}

Source: generalized and formed according to data (Ministry of Economic Development and Trade of Ukraine, 2013; National Bank of Ukraine, 2020; State Statistic Service of Ukraine, 2020; State Treasure Service of Ukraine, 2020; Knoema Enterprise, 2020; PFTS Stock Exchange, 2020; National Commission on Securities and Stock Market, 2020; Ministry of Economic Development and Trade of Ukraine, 2015).

The data Table 2 shows that over the years 2009-2018. There was a general reduction in the integral index of financial security in Ukraine 7.4\%, while in 2011 it reached a maximum value of 0.58 , which corresponded to an unsatisfactory level, and in 2015 - a minimum value of 0.39 , which corresponded to a dangerous level. The values of the integrated indicator of financial security in other years corresponded to an unsatisfactory level.

It should also be noted that the worst impact on the integrated indicator was caused by the debt security sub-index, which in all years except 2011 was the lowest compared to other components of financial security. Instead, the integrated indicator was best influenced by the budget security sub-index, which reached the highest level in all years except 2013-2014, compared to other components of financial security. In addition, the contribution of budget security to the financial, according to the weighting factor, is also the largest and is $20.2 \%$. To visualize the results we construct Figure 1.

To verify the correctness of the calculations of the level of financial security of Ukraine (see Table 2 and Figure 1), we will conduct a regression analysis of the dependence of the integrated indicator of financial security of Ukraine (resulting feature) from 6 sub-indices (factor features): banking security, non-bank financial market security currency security and monetary security. To do this, use the package "Data Analysis" in MS Excel, preselecting "constant - zero", because if all components are equal to 0 , the integral index will also be equal to 0 . The results of regression analysis are illustrated by Figure 2 . 


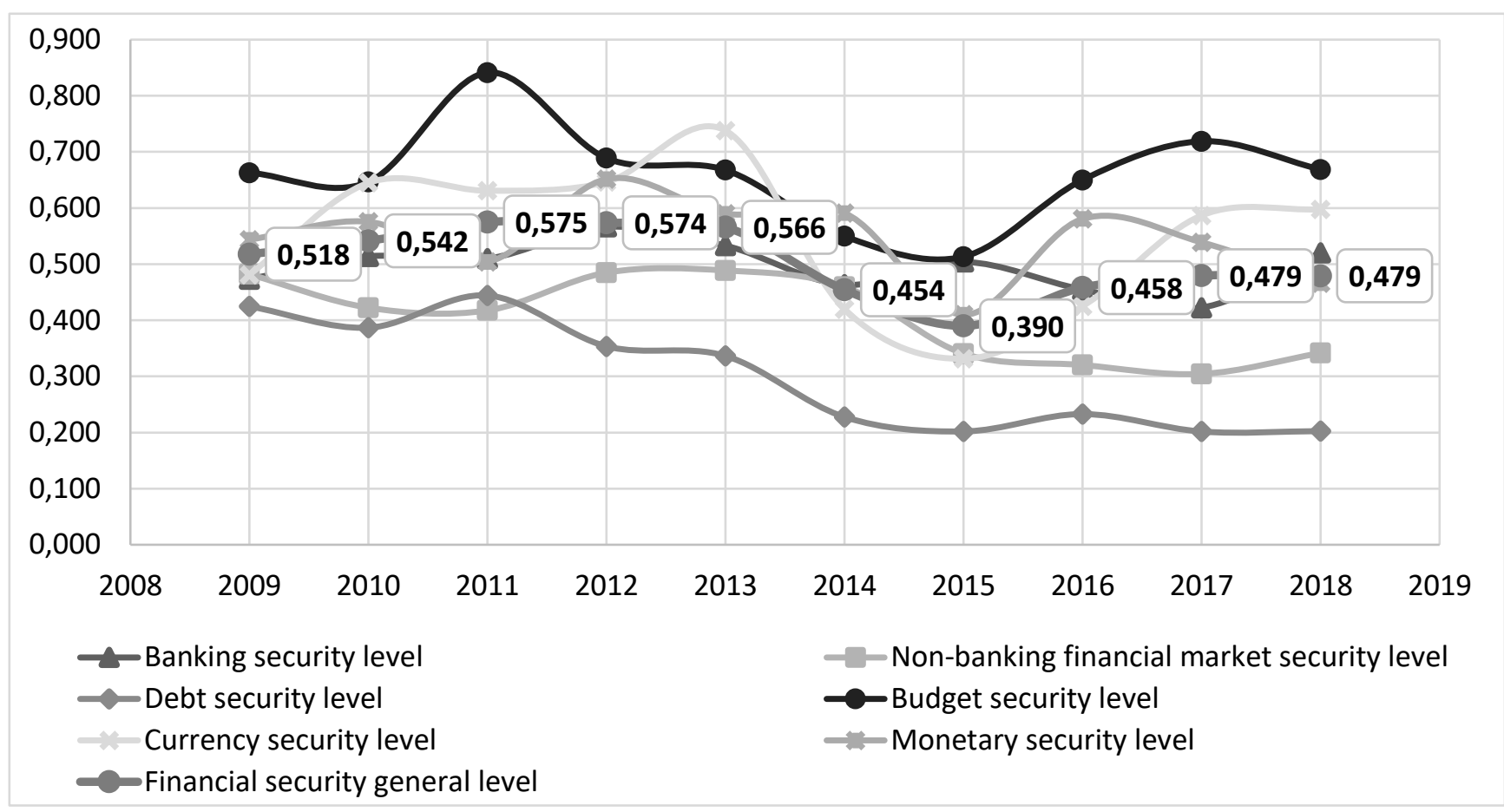

Fig. 1. Dynamics of financial security components of Ukraine in 2009-2018

Source: author's calculations.

SUMMARY OUTPUT

\begin{tabular}{l|r}
\hline \multicolumn{2}{c}{ Regression statistics } \\
\hline Multiple R & 1 \\
\hline R Square & 1 \\
\hline Adjusted R Square & 0,75 \\
\hline Standard Error & $1,71626 \mathrm{E}-07$ \\
\hline Observations & 10 \\
\hline
\end{tabular}

ANOVA

\begin{tabular}{l|r|r|r|r|r|}
\hline & $d f$ & $S S$ & \multicolumn{1}{c}{$M$} & $F$ & Significance $F$ \\
\hline Regression & 6 & 2,568399979 & 0,428066663 & $1,45327 \mathrm{E}+13$ & $2,792 \mathrm{E}-20$ \\
\hline Residual & 4 & $1,17822 \mathrm{E}-13$ & $2,94555 \mathrm{E}-14$ & & \\
\hline Total & 10 & 2,568399979 & & & \\
\hline
\end{tabular}

\begin{tabular}{|c|c|c|c|c|c|c|}
\hline & Coefficients & Standard Error & t Stat & P-value & Lower 95\% & Upper 95\% \\
\hline Intercept & 0 & $\# \mathrm{n} / \mathrm{d}$ & $\# \mathrm{n} / \mathrm{d}$ & $\# \mathrm{n} / \mathrm{d}$ & $\# \mathrm{n} / \mathrm{d}$ & $\# \mathrm{n} / \mathrm{d}$ \\
\hline Banking security sub-index & 0,17230115 & $1,25388 \mathrm{E}-06$ & 137414,374 & $1,68276 \mathrm{E}-20$ & 0,172297669 & 0,1723046 \\
\hline Non-banking financial market security sub-index & 0,106801719 & 1,71302E-06 & 62346,95149 & $3,97091 \mathrm{E}-19$ & 0,106796963 & 0,1068065 \\
\hline Debt security sub-index & 0,174599653 & 1,10561E-06 & 157922,1691 & $9,6467 \mathrm{E}-21$ & 0,174596583 & 0,1746027 \\
\hline Budget security sub-index & 0,20230082 & $9,1492 \mathrm{E}-07$ & 221113,0312 & $2,51012 \mathrm{E}-21$ & 0,202298279 & 0,2023034 \\
\hline Currency security sub-index & 0,168598918 & $6,18244 \mathrm{E}-07$ & 272706,1827 & $1,08485 E-21$ & 0,168597201 & 0,1686006 \\
\hline Monetary security sub-index & 0,175297971 & $1,06138 \mathrm{E}-06$ & 165160,0719 & $8,06364 \mathrm{E}-21$ & 0,175295024 & 0,1753009 \\
\hline
\end{tabular}

\section{Fig. 2. The results of checking the correctness of the calculations of the integrated indicator of financial security by means of regression analysis}

Source: author's calculations using MS Excel.

The data shown in Figure 2 show that there is a functional relationship between the integrated indicator of financial security and sub-indices, as the coefficients of multiple correlation and determination are 1 . The reliability of the calculations is confirmed by the regression coefficients, each of which completely coincides with the corresponding weight (see Table 2). Therefore, the reliability of the obtained level of financial security of Ukraine in 2009-2018 is not in doubt and it can be used in further studies of the place and role 
of budget policy in the system of financial security.

Given the predominance of the budget component both in the structure and in the level of financial security of Ukraine, it is possible to form a scientific hypothesis about the exceptional importance and primacy of budget policy in the system of financial security of the state. Thus, given that the regulator of the banking services market in Ukraine is the $\mathrm{NBU}$, the results of its activities have an impact not only on the state of the banking system, but also on financial security. In the context of budget policy, the result of the NBU's activity is the receipt of the state budget's net profit. In this regard, an additional indicator of the impact of fiscal policy on the banking component of financial security, we offer an indicator of the share of revenues from the NBU in state budget revenues.

Analyzing the security of the non-banking financial market of Ukraine, it should be noted that the Guidelines for calculating the level of economic security of Ukraine (Ministry of Economic Development and Trade of Ukraine, 2013) ignored the market of private pension provision, which is an alternative to national mandatory pension insurance. and can be considered as a factor in reducing the PFC deficit, which is covered by the State Budget of Ukraine. Therefore, an additional indicator of the impact of fiscal policy on the security of the non-banking financial market of Ukraine is the ratio of pension contributions of private pension funds to PFC own revenues.

Based on the results of Ukraine's debt security analysis, it can be concluded that among the indicators there are no indicators directly related to fiscal policy, which is unfair, as the process of public debt service is an integral part of fiscal policy, which is a direct effect on debt security. In view of the above, we offer the following additional indicators of the impact of fiscal policy on the debt component of financial security of the state:

1) revenues from IGLBs in \% to the consolidated budget expenditures;
2) the share of costs for servicing and repayment of public debt in the consolidated budget expenditures, \%.

We also consider it appropriate to add to the 4 indicators of budget security the indicator of expenditures for servicing and repayment of public debt in \% of GDP.

Analysis of currency security from the standpoint of the impact of fiscal policy on financial security involves a combination of exchange rate dynamics with budget dynamics. In this regard, we consider it appropriate to offer an additional indicator of the impact of fiscal policy on the currency component of financial security of the consolidated budget revenues in USD, which can be used to study the effectiveness of fiscal policy in the context of the devaluation of the national currency and its impact on the currency component of financial security. Thus, the growing dynamics of consolidated budget revenues in dollars. The United States will have a positive impact on financial security, and the downturn will have a negative one.

Analyzing the indicators of monetary security, it should be noted that the share of consumer loans to households in the overall structure of loans to residents does not contain the content by which it is possible to realistically assess the level of both monetary and financial security in general. We believe that from the standpoint of the impact of fiscal policy on financial security, the indicator of the volume of consumer loans to households, \% of household income, will be more acceptable. This indicator reflects the part of aggregate demand stimulated by lending to households, which provides an additional increase in sales of goods, works, services, and, accordingly, additional revenues to the state budget from VAT. Also, the methodology does not take into account the participation of the state in the lending process, so we consider it appropriate to offer an indicator of the share of lending in the consolidated budget.

\section{Conclusions.}

Thus, in the course of the study of methodological support for assessing the financial 
security of the state, the following results were obtained:

firstly, based on comparative analysis of guidance on the assessment of the level of economic security of Ukraine (Pyrozhkov, 2003), the methodology for determining the level of economic security of Ukraine (Ministry of Economy of Ukraine, 2007) and Guidelines on the calculation of economic security of Ukraine (Ministry of Economic Development and Trade of Ukraine, 2013) it was substantiated that the most relevant, comprehensive and knowledge-intensive is the latter, so, despite the existing shortcomings, the need for its use in determining the level of financial security of Ukraine;

secondly, calculations and rationing of 32 financial security indicators were carried out according to the Guidelines for calculating the level of economic security of Ukraine (Ministry of Economic Development and Trade of Ukraine, 2013) for 2009-2018, based on which 6 sub-indices of its functional components and integrated indicator, which at the end of 2018 amounted to 0.48, having decreased over 10 years by $-7.4 \%$, revealed an unsatisfactory level of financial security of Ukraine; thirdly, all components of financial security of the state, except for budget security, do not take into account the impact of budget policy, so the author proposed additional indicators, in particular for banking security, the share of revenues from the NBU in state budget revenues; for the security of the nonbanking financial market - the ratio of the amount of pension contributions of non-state pension funds to PFC own revenues; for debt security - revenues from IGLBs in \% to the consolidated budget expenditures and the share of expenditures for servicing and repayment of public debt in the consolidated budget expenditures; for budget security - costs of servicing and repayment of public debt in \% of GDP; for currency security - consolidated budget revenues in USD; for monetary security - the volume of consumer loans granted to households, in \% of household income and the share of lending in the consolidated budget expenditures;

fourthly confirmed the reliability of the calculations and weighting coefficients in the integral index sub-indices financial security based on regression analysis, where the factor variable sub-index taken, and the resulting feature - integrated measure of financial security.

\section{References}

Biloshkurska, N. V., Biloshkurskyi, M. V. and Omelyanenko, V. A. (2018), "Evaluation of Ukrainian industry innovative development with a technological progress parameter", Scientific Bulletin of Polissia, vol. 13, issue 1, part 2, pp. 23-28. doi: https://doi.org/10.25140/2410-9576-2018-2-1(13)-23-28

Bondaruk, T. H., Bondaruk, O. S. and Kulish, A. P. (2019), "Influence of risks and state economic security treatments on foreign direct investments", Economies' Horizons, no. 1(8), pp. 77-88. doi: http://dx.doi.org/10.31499/2616-5236.1(8).2019.177760

Goede, M. (2017), "Financial security", Finance and Society, vol. 3, no. 2, pp.159-172. doi: https://doi.org/10.2218/finsoc.v3i2.2575

Guryanova, L. S., Klebanova, T. S., Milevskiy, S. V., Nepomnyaschiy, V. V. and Rudachenko, O. A. (2017), "Models for the analysis of the state's financial security indicators dynamics", Financial and credit activity: problems of theory and practice, vol. 1, no. 22, pp. 254-264. doi: https://doi.org/10.18371/fcaptp.v1i22.110179

Haber, J. A., Bukhtiarova, A., Chorna, S., Iastremska, O. and Bolgar, T. (2018), "Forecasting the level of financial security of the country (on the example of Ukraine)", Investment Management and Financial Innovations, vol. 15, no. 3, pp. 304-317. doi: https://doi.org/10.21511/imfi.15(3).2018.25

Han, R. (2018), “Financial internationalization and financial security issues”, Open Access Library Journal, vol. 5, no. 9, pp. 1-7. doi: https://doi.org/10.4236/oalib.1104874

Ivanova, O. B., Romanova, T. F., Kostoglodova, E. D. and Romanov, D. G. (2017), "Strategic directions of the country's ensuring financial security”, European Research Studies Journal, vol. 20, issue 3, part B, pp. 461-468. 
Knoema Enterprise (2020), “Ukraine - Emerging Market Bond Index (JPM Total Return Index)”, available at: https://knoema.ru/WBGEM2017Mar/world-bank-global-economic-monitor-monthlyupdate?tsId=1079690 (Accessed 22 January 2020).

Lyons, A. C., Grable, J. E. and Joo, S.-H. (2018), “A cross-country analysis of population aging and financial security", The Journal of the Economics of Ageing, vol.12, pp.96-117. doi: https://doi.org/10.1016/i.jeoa.2018.03.001

Ministry of Economic Development and Trade of Ukraine (2013), Order "On approval of Methodological recommendations for calculating the level of economic security of Ukraine", available at: https://zakon.rada.gov.ua/rada/show/v1277731-13 (Accessed 22 January 2020).

Ministry of Economic Development and Trade of Ukraine (2015), “About approval of Methodical recommendations on complex estimation of volumes of unproductive outflow (export) of financial resources outside Ukraine", available at: https://zakon.rada.gov.ua/rada/show/v0286731-15\#n151 (Accessed 22 January 2020).

Ministry of Economy of Ukraine (2007), Order "On approval of the Methodology for calculating the level of economic security of Ukraine”, available at: https://zakon.rada.gov.ua/rada/show/v0060665-07 (Accessed 22 January 2020).

Munyon, T. P., Carnes, A. M., Lyons, L. M. and Zettler, I. (2019), “All about the money? Exploring antecedents and consequences for a brief measure of perceived financial security", Journal of Occupational Health Psychology, Advance online publication. doi: https://doi.org/10.1037/ocp0000162

National Bank of Ukraine (2020), "Statistics", available at: https://bank.gov.ua/statistic (Accessed 22 January 2020).

National Commission on Securities and Stock Market (2020), “Annual reports", available at: https://www.nssmc.gov.ua/en/about-us/annual-reports/ (Accessed 22 January 2020).

PFTS Stock Exchange (2020), "PFTS Index", available at: https://pfts.ua/trade-info/indexes/shares-indexes (Accessed 22 January 2020).

Ponomarenko, T. V., Prokopenko, O. V., Slatvinskyi, M. A., Biloshkurska, N. V., Biloshkurskyi, M. V. and Omelyanenko, V. A. (2019), "National investment and innovation security assessment methodology", International Journal of Mechanical Engineering and Technology, vol. 10, issue 2, pp. 847-857, available at: http://www.iaeme.com/MasterAdmin//Tournal_uploads/IJMET/VOLUME_10_ISSUE_2/IJMET_10_02_088.pdf (Accessed 22 January 2020).

Pyrozhkov S. I. (ed.) (2003), Metodychni rekomendatsii shchodo otsinky rivnia ekonomichnoi bezpeky Ukrainy [Guidelines for assessing the level of economic security of Ukraine], National Institute of International Security Problems, Kyiv, Ukraine, 63 p.

Semjonova, N. (2016), "Financial security in the Baltic states: comparison with selected EU countries", Economics and Business, vol. 29, issue 1, pp. 90-95. doi: https://doi.org/10.1515/eb-2016-0026

Siemiątkowski, P. (2017), "External financial security of the European Union member states outside the Eurozone”, Journal of International Studies, vol. 10, no. 4, pp. 84-95. doi: https://doi.org/10.14254/2071$\underline{8330.2017 / 10-4 / 6}$

State Statistic Service of Ukraine (2020), "Statistical Information”, available at: http://www.ukrstat.gov.ua/ (Accessed 22 January 2020).

State Treasure Service of Ukraine (2020), "Reporting”, available at: https://www.treasury.gov.ua/ua/file-storage/vikonannya-derzhavnogo-byudzhetu (Accessed 22 January 2020).

Telnova, H. V. and Malovanyy, B. Yu. (2019), "Methodical approach to the assessment of financial security of the region in the context of decentralization”, Economies' Horizons, no. 2(9), pp. 49-57. doi: http://dx.doi.org/10.31499/2616-5236.2(9).2019.195659

Thompson, G. F. (2017), “Time, trading and algorithms in financial sector security”, New Political Economy, vol. 22, issue 1, pp. 1-11. doi: https://doi.org/10.1080/13563467.2016.1183116

Tkachenko, V., Kwilinski, A, Korystin, O., Svyrydiuk, N. and Tkachenko, I. (2019), “Assessment of information technologies influence on financial security of economy", Journal of Security and Sustainability Issues, vol. 8, no. 3, pp. 375-385. doi: http://doi.org/10.9770/issi.2019.8.3(7)

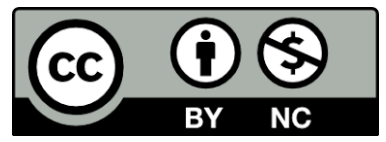

Цей твір ліцензовано на умовах Ліцензії Creative Commons «/з Зазначенням Авторства - Некомерційна 4.0 Міжнародна» (CC BY-NC 4.0). This is an open access journal and all published articles are licensed under a Creative Commons "Attribution-NonCommercial 4.0 International" (CC BY-NC 4.0). 